\title{
Psychiatrists under stress
}

\author{
Susan M. Benbow and David J. Jolley
}

\section{Analysis}

Mental health officer status allowed psychiatrists early retirement with full pension rights. Did the Department of Health introduce this privilege to increase recruitment to the 'asylums' or was this official recognition that working with mental illness is particularly stressful?

Department of Health figures suggest that few psychiatrists took advantage of this option in the past. Now psychiatrists are retiring earlier (Kendell \& Pearce, 1997) and recruitment to the speciality is insufficient to maintain consultant numbers (Storer, 1997). Mental health officer status has been lost, psychiatrists are no different from the other doctors.

Evidence suggests that doctors in general are under great stress. As a group they are more prone to symptoms of anxiety/depression and are more likely to misuse alcohol or other substances (Holmes, 1997). Compared with the general population, they have increased rates of cirrhosis, road traffic accidents and suicide (Margison, 1987). Psychiatrists have been known to be at increased risk of stress-related disorders for some time (Rich \& Pitts, 1980). Advances in Psychiatric Treatment recently devoted an issue to stress and burnout within the profession (Vol. 3, Issue 5). Review papers set out current knowledge of the aetiology, prevalence and nature of stress among psychiatrists, within a context of high stress levels in health professionals generally, includng trainees, practitioners and managers (Caplan, 1994).

\section{Genesis}

The British Medical Association (1992) identified broad categories of stress, including intrinsic characteristics of the job, organisational structure and climate, relationships within work and demands of career development. Personality factors (Deary et al, 1996) and factors asociated with personal circumstances (Guthrie et al, 1998) can be added to these. Management theorists have similarly considered work-force well-being and productivity. 'Stress' (perceived as demand or challenge) may be positively stimulating and desirable, but becomes harmful in certain circumstances ('strain'), resulting in symptoms of reduced well-being and impaired performance.

Herzeberg (1966, 1968) identified 'motivators' (factors associated with the positive achievement of satisfaction) which include achieving outcomes important to the individual, recognition of quantity and quality of work done, responsibility for the development and work of others. personal advancement and salary. Lack of these leads to demotivation, reduced productivity and the likelihood of emerging symptomatology. 'Hygiene' factors are also necessary to avoid dissatisfaction and strain. These include policy which is understood and owned by the individual, supervision to ensure skills meet the demands of the job (with retraining if necessary). supervision of progress, salary and facilities.

Work as a consultant psychiatrist can be highly stimulating and enjoyable, but the workload may be excessive. Many Trusts are staffed at a level below that recommended by the College (Royal College of Psychiatrists, 1992) and qualified staff may not be available to fill funded posts. Thus many services have a few staff or temporary staff lacking commitment or qualifications. Established consultants may face excessive demands, or work alongside colleagues who do not share their aspirations. Recognition and additional rewards tend to go to those involved in well-staffed and well-regarded units. Locally determined Discretionary Points may redistribute monies, but B, A and A+ awards will continue to be given to people recognised nationally and internationally in terms of academic excellence rather than service delivery. Many consultants miss out on rewarding aspects of their job (e.g. teaching, research and training) because of excessive service demands (Guthrie \& Black, 1997).

Changes in National Health Service policy over recent years have been linked with dissatisfaction. low morale. poor recruitment and early retirement in general practice and other branches of medicine (Handysides, 1994; Richards, 1997). Change in the mental health service has been greater than in other areas (Secretary of State for Health, 1996). Although motivated by a desire to improve services for patients and their families, these changes have progressed without full recognition of their implications. Has safety of patients, their families, the general public and staff been put at risk 
(Eastman, 1997) in the move away from hospital care? Do enquiries and bureaucratic devices (such as the Care Programme Approach) allocate blame (Watson, 1997), rather than improve services?

Consultants are expected (by themselves and others) to work long hours and to play a number of roles (responsible clinician, team member, perhaps team leader, manager, budget holder, teacher, researcher, counsellor) in various settings (wards, day hospitals, the community). Role ambiguity, conflict and overload are associated with the emergence of stress symptoms (Handy, 1993).

\section{Therapeutic strategies}

Individuals may adopt strategies to limit demands on them, 'that's not my job' etc. This may help in the short term but exacerbates tensions in other parts of the service which may then feed back to the individual concerned. Solutions will require commitment from the mental health professions, management and the National Health Service Management Executive.

Although psychiatrists could be better trained for the realities of practice, a major revision of how consultants are supported and supervised would enhance their work (Harper \& Minghella, 1997). Self-monitoring schedules might identify pressures and signs of decompensation, allowing consideration of avoidance/regenerative activity. Could high-calibre staff be distributed more equitably/optimally and enhance the health and productivity of the workforce? This would involve alternative methods of evaluating achievement and allocating reward and might reverse the trend to a two-tier system. Extending restructuring into undergraduate and postgraduate training would aim to prevent and promote good health within the profession, linked with mechanisms to identify those who still get into difficulty (Brandon, 1997).

\section{Redefinition of priorities}

Support and supervision needs to be conducted in a framework which allows individuals and organisations to change over time. Neither can stay still and remain healthy (Handy, 1994). Some consultants will change their interests and disciplines. Others may change post. These mechanisms allow re-energisation. Relative allocation of time and energy to service, teaching, research, family and wider interests will vary with time and circumstances. This needs to be understood and accepted by individuals and the organisations of which they form part.

\section{References}

BRANDON. S. (1997) Persuading the sick or impaired doctor to seek treatment. Advances in Psychiatric Treatment, 3. 305-311.
BRITISH MEDICAL ASSOCIATION (1992) Understanding stress. In Stress and the Medical Profession. pp. 5-12. London: BMA.

CAPLAN, R. P. (1994) Stress, anxiety and depression in hospital consultants, general practitioners and senior health service managers. British Medical Joumal, $\mathbf{s 0 9}$. 1261-1263.

DeARY, I. J., Blenkin, H., ENDLER, N. S., et al (1996) Models of job-related stress and personal achievement among consultant doctors. British Journal of Psychology. 87, 3-29.

Eastman, N. (1997) The Mental Health (Patients in the Community) Act 1995. British Journal of Psychiatry. 170, $492-496$.

GuTHRIE, E. \& BLACK, D. (1997) Psychiatric disorder, stress and burnout. Advances in Psychiatric Treatment, 3. 275-281.

- TAtTon, T. WillaAms, E., et al (1998) Sources of stress. psychological distress and burnout in psychiatrists: a comparison of junior doctors. senior registrars and consultants. Psychiatric Bulletin, in press.

HANDY, C. (1993) Understanding Organisations. Harmondsworth: Penguin Books.

- (1994) The Empty Raincoat. London: Hutchinson.

HANDYSIDES, S. (1994) Morale in general practice: is change the problem or the solution. British Medical Joumal. 308. 32-34.

HARPER, H. \& Minghella, E. (1997) Pressures and rewards of working in community mental health teams. Mental Health Care, 1, 18-21.

HERZEBERG, F. (1966) Work and the Nature of Man. Grand Rapids: World Publishing.

- (1968) One more time: how do you motivate employers. Harvard Business Review, 46.

HOLMES, J. (1997) Mental health of doctors. Advances in Psychiatric Treatment, 3, 251-253.

KENDELL, R. E. \& PEARCE. A. (1997) Consultant psychiatrists who retired prematurely in 1995 and 1996. Psychiatric Bulletin, 21, 741-745.

MARGISON, F. R. (1987) Stress in psychiatrists. In Stress in Health Professionals (eds R. Payne \& J. Firth-Cozens). pp. 107-124. Chichester: John Wiley.

Rich, C. L. \& PITTS, F. N. (1980) Sulcide by psychiatrists: a study of medical specialists among 18,730 consecutive physician deaths during a five year period 1967-72. Journal of Clinical Psychiatry, 41, 261-263.

RICHARDS. T. (1997) Disillusioned doctors need a better balance between service commitment and education. British Medical Journal, 314, 1705-1706.

ROYAL COLLEGE OF PSYCHIATRISTS (1992) Mental Health of the Nation. The Contribution of Psychiatry (Councll Report CR16). London: Royal College of Psychiatrists.

SECRETARY OF STATE FOR HEALTH (1996) The National Health Service: A Service With Ambitions. London: HMSO.

STORER, D. (1997) Prematurely retiring consultant psychiatrists. Psychiatric Bulletin, 21, 737-738.

WATSON, P. E. (1997) CPA should it carry a government health warning. Psychiatric Bulletin, 21, 432-434.

*Susan M. Benbow, Consultant Psychiatrist for the Elderly, York House, Manchester Royal Infirmary, Oxford Road, Manchester M13 9BX and David J. Jolley, Professor in Old Age Psychiatry, Penn Hospital, Penn Road. Wolverhampton, West Midlands WV4 5HN

*Correspondence 